J. Lake Sci. (湖泊科学), 2011, 23(6): 910-918

http: //www.jlakes.org. E-mail : jlakes@niglas.ac.cn

(c) 2011 by Journal of Lake Sciences

\title{
黄河中游北洛河宜君段全新世特大洪水及其气候背景研究”
}

\author{
王夏青, 黄春长, 庞奖励,查小春, 周亚利, 王恒松, 顾洪亮, 周 芳, 魏海燕 \\ ( 陕西师范大学旅游与环境学院, 西安 710062)
}

\begin{abstract}
摘 要: 通过对黄河中游北洛河的野外考察, 在宜君基岩峡谷全新世风成黄土一土壤剖面中发现三层古洪水滞流沉积物 (SWD). 野外观察和室内实验分析, 证明它们是北洛河特大洪水悬移质泥沙在高水位滞流环境下的沉积物. 这些古洪水 滞流沉积层夹在全新世中期古土壤之内, 其每一层记录了一期特大洪水事件. 利用古水文学方法恢复了古洪水洪峰水位 和流量, 确定三期古洪水的洪峰流量介于 $13600-14100 \mathrm{~m}^{3} / \mathrm{s}$ 之间. 这就将北洛河中游洪水数据序列延长到万年尺度, 为 更加精确地建立洪峰流量-频率关系奠定了基础. 这些结果对北洛河流域水利工程建设和防洪减灾提供了可靠依据. 根 据土壤地层和气候地层对比,结合 OSL 测年数据, 确定这三期古洪水的发生年代为 $8000-7800 \mathrm{aBP}(\mathrm{SWD1}), 6000-5000$ $\mathrm{aBP}(\mathrm{SWD} 2)$ 和 4200-4000 aBP (SWD3). 它们与全新世大暖期三个气候突变事件密切相关,是气候不稳定状态下, 区域 水文系统极端性变化的重要表现. 这就为深人理解全球变化对于半干旱地区气候水文系统的影响提供了新的证据.
\end{abstract}

关键词: 北洛河;黄河中游;古洪水;滞流沉积物;全新世大暖期;气候突变

\section{Holocene palaeo-floods and climatic changes in the Yijun reaches of the Beiluohe River, middle reaches of the Yellow River}

WANG Xiaqing, HUANG Chunchang, PANG Jiangli, ZHA Xiaochun, ZHOU Yali, WANG Hengsong, Gu Hongliang, ZHOU Fang \& WEI Haiyan

(College of Tourism and Environmental Sciences, Shanxi Normal University, Xi'an 710062, P. R. China)

Abstract: Holocene palaeo-flood slackwater deposits (SWD) were found in Yijun reaches of the Beiluohe River in the middle reaches of the Yellow River. They were identified by sedimentary criteria during fieldwork initially. A set of three beds of palaeo-flood SWD was interbedded in the Holocene loess-soil sequence within the cliff riverbanks. Each of the SWD represents one individual palaeo-flood event. The analytical results of grain-size distribution and magnetic susceptibility indicate that these SWD beds were deposited from the suspended sediment load in the floodwater. According to climatic and stratigraphic correlation with the OSL dated Holocene profiles in the region, these palaeo-flood events occurred during $8000-7800$ aBP (SWD1), $6000-5000$ aBP (SWD2) and $4200-4000 \mathrm{aBP}$ (SWD3), respectively. The palaeo-flood peak discharges were calculated by hydrological models and estimated to between 13600 and $14100 \mathrm{~m}^{3} / \mathrm{s}$. The archives of flood data were therefore extended to a time-scale of over 10000 years. A more reliable flood peak discharge and frequency relationship was established accurately. These results are very important in hydraulic engineering and mitigating flood hazard in Beiluohe River basin. These palaeo-floods are well correlated to the abrupt climatic events occurred during the mid-Holocene Climatic Optimum. They provide solid evidence for investigating the social impacts of per-historical floods on the decline of the Neolithic civilizations in China's monsoon regions.

Keywords: Beiluohe River; mildle reaches of the Yellow River; palaeo-flood; slackwater deposits; Holocene Climatic Optimum; abrupt change

全新世古洪水事件是流域水文过程对气候变化的响应,特大洪水的发生往往与气候突变事件密切联 系.通过对基岩峡谷古洪水滞流沉积地层所记录的古洪水事件进行研究,能够重建古洪水水位和流量,恢

* 国家自然科学基金重点项目 (41030637,40771018) 和中央高校基本科研业务费专项基金项目 ( GK200901007, GK200902020) 联合资助. 2010-12-18 收稿;2011-03-07 收修改稿. 王夏青, 1986 年生, 男, 硕士研究生; Email: xiaqing@stu.snnu.edu.cn. 
复万年尺度的洪水资料, 延长洪水水文数据的时间序列, 从而更精确地确定洪水频率和洪峰流量的关系. 因此,古洪水研究有助于水利工程建设、水资源发展和防治洪水灾害. 古洪水研究主要是鉴别和分析古 洪水滞流沉积物 (SWD), 借此恢复古洪水水位、流量及洪水发生频率 ${ }^{[1-7]}$. 目前, 国内外诸多学者已经 对众多河流进行了古洪水研究, 明确了古洪水滞流沉积物的沉积学性质和特征, 并提出了恢复古洪水 洪峰水位和流量的方法 ${ }^{[8-18]}$. 全新世古洪水研究成果在国内外被逐渐地应用到了水利水电工程的设计 建设中.

北洛河流域位于黄河中游黄土高原中部, 属大陆性半干旱季风气候. 该区域暴雨发生频率高, 土壤侵蚀 严重, 是黄河中游悬移质泥沙的重要来源区. 突发性洪水是流域的主要自然灾害. 但该流域实测洪水序列 短, 历史记录洪水资料少, 不足以建立有效的洪水序列 ${ }^{[19-21]}$. 因此,利用古洪水水文学方法恢复万年尺度特 大洪水的水文资料是非常必要的. 通过对北洛河中游基岩峡谷的实地考察, 在宜君段全新世沉积地层剖面 发现古洪水滞流沉积层. 根据野外观察和室内分析,进行了水文重建和频率分析, 为北洛河流域水利工程建 设,防治洪水灾害和水资源开发提供了可靠的依据. 同时对深人了解区域水文系统对于全球变化的响应规 律有着十分重要的理论价值.

\section{1 研究河段概况}

北洛河发源于陕西榆林市定边县白于山南麓的草梁山, 由西北流向东南, 流经陕西榆林、延安、铜川、渭南 4 个地 (市) 的 16 个县 (区) , 在大荔县三河口注人渭河. 北洛河干流全长 $680.3 \mathrm{~km}$, 年平均流量 $24.6 \mathrm{~m}^{3} / \mathrm{s}$, 年平均径流总量 $9 \times 10^{8} \mathrm{~m}^{3}$, 年平均输沙量 $0.833 \times 10^{8} \mathrm{t}$, 河道平均比降 $1.53 \%$. 从白于山河源至甘泉县道佐 埠为上游, 河长 $297 \mathrm{~km}$, 河道平均比降 $2.88 \%$; 道佐埠至白水河口为中游, 河长 $229 \mathrm{~km}$, 平均比降 $2.19 \%$; 白水 河口以下为下游, 河长 $154 \mathrm{~km}$, 平均比降 $0.77 \%$. 北洛河流域处于陕北黄土高原地区, 总面积为 $26905 \mathrm{~km}^{2}$, 其水系呈羽状分布, 支流众多, 流域中较大的支流有葫芦河、沮河、周水河等 ${ }^{[22-25]}$. 流域地处暖温带, 属半干 旱大陆性季风气候, 年平均气温 $9.3^{\circ} \mathrm{C}$, 多年平 均降水量为 $548 \mathrm{~mm}$, 以大气降水为主, 降水量年 际变化大,年内降水分配不均, $6-9$ 月降水量占 全年总降水量的 70\% 左右, 且多为暴雨,年径流 量的 $60 \%$ 也集中在这四个月,流域的洪水均系暴 雨所致,暴雨多为雷暴雨, 洪水 $90 \%$ 以上发生在 $7-8$ 月间 ${ }^{[26]}$. 流域水土流失严重, 流失面积占流 域总面积的 $64.2 \%$,其中位于黄土丘陵沟壑区的 定边、靖边、吴旗、志丹等县, 植被稀疏, 土壤侵蚀 模数高达 $1.48 \times 10^{4} \mathrm{t} / \mathrm{km}^{2}$, 为洛河流域的主要产 沙区,也是黄河中游粗泥沙集中来源区 ${ }^{[27]}$. 北洛 河在吴旗、刘家河、交口河、洑头、朝邑等处设有 水文站测报汛情.

本文研究区位于交口河水文站和洑头水文站 之间 (图 1, CHZ). 北洛河洑头水文站建于 1933 年, 是北洛河下游干流控制站, 控制断面以上河长 $550 \mathrm{~km}$, 控制面积 $25645 \mathrm{~km}^{2}$, 河道平均比降 $3.15 \%$, 多年平均流量 $23.2 \mathrm{~m}^{3} / \mathrm{s}$, 多年平均含沙量为 $119 \mathrm{~kg} / \mathrm{m}^{3}$, 多年平均径流总量 $9.25 \times 10^{8} \mathrm{~m}^{3}$, 多 年平均输沙量 $0.89 \times 10^{8} \mathrm{t}$. 本站实测最大洪峰流 量为 $6280 \mathrm{~m}^{3} / \mathrm{s}(1994$ 年 9 月 1 日 8 时), 水位涨 幅 $12.29 \mathrm{~m}$, 流量涨率为 $1790 \mathrm{~m}^{3} / \mathrm{s}$, 洪水过程径流

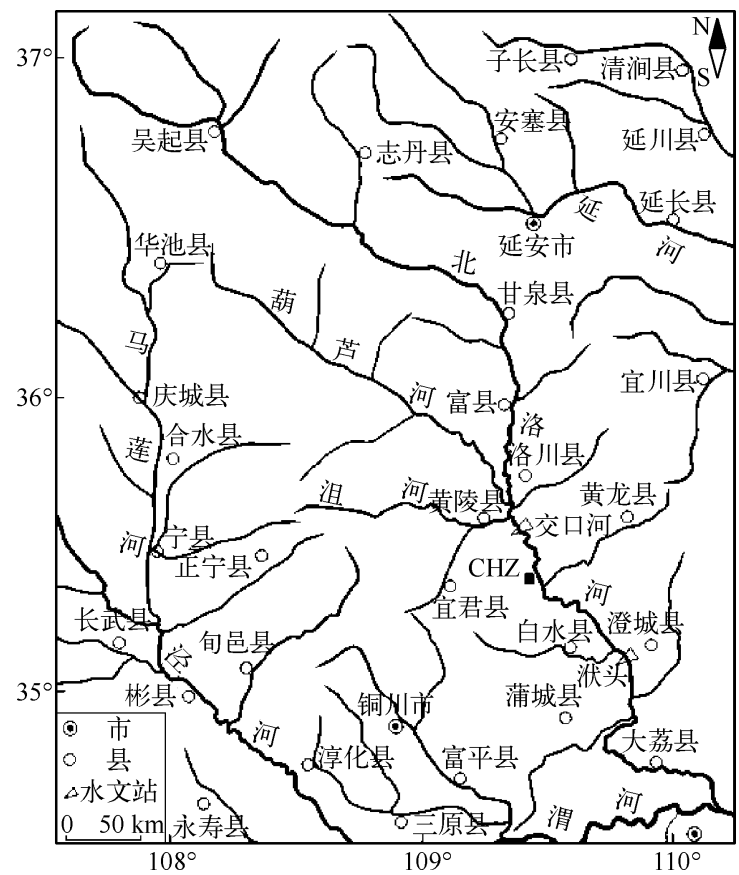

图 1 北洛河水系图

Fig. 1 River system of the Beiluohe River 总量为 $1.9381 \times 10^{8} \mathrm{~m}^{3[23]}$. 


\section{2 研究地点、沉积剖面及实验方法}

在对北洛河中游进行野外考察的过程当中, 我们在宜君县河段多处发现夹有古洪水滞流沉积层的全新 世沉积剖面. 本文选择夹有三期古洪水滞流沉积层的全新世风成黄土一土壤剖面进行深人研究. 由于该地点 距蔡河站较近, 故命名为蔡河站地点 (CHZ). CHZ 剖面位于北洛河干流基岩峡谷右岸, 全新世黄土一古土壤 地层出露完整, 人为扰动很少, 土壤学和沉积学特征保存完整. 尤其是其中发现有三层古洪水滞流沉积物 (SWD) 夹在古土壤 $\mathrm{S}_{0}$ 之中, 层次清晰, 呈现出波状水平状层理. 它们将古土壤 $\mathrm{S}_{0}$ 分隔为 4 个亚层, 清晰地表 明每一层 SWD 都记录了一个单独的古洪水事件. 这些古洪水滞流沉积层与其上覆、下伏的古土壤层在颜 色、粒度、结构等方面有着非常明显的区别. 通过对其沉积学宏观特征进行分析, 在详细观察和描述后, 自剖 面顶部向下按照 $5 \mathrm{~cm}$ 厚度连续采样, 共采得 60 个样品. 在 CHZ 剖面旁的小路上发现了 1994 年洪水洪痕, 记 录该洪痕位置并根据洪痕验证古洪水的洪峰流量计算. 根据野外宏观特征及室内实验分析, 将整个剖面自 上而下分为 11 层, 其基本特征如下:

(1) $0-50 \mathrm{~cm}$, 表土层 (MS), 浊棕色, 粉沙质地, 团粒结构, 多根系, 含大量䖳蚂洞穴和粪粒, 中间夹有坡 积物角砾石块;

（2） $50-80 \mathrm{~cm}$, 全新世黄土层 $\left(\mathrm{L}_{0}\right)$, 浊橙色, 沙质粉沙土, 块状结构, 孔隙中含有钻质假菌丝体;

(3) $80-100 \mathrm{~cm}$, 古土壤层 $\left(\mathrm{S}_{0 \text { 上 }}\right)$, 浊棕色, 粉沙质地, 团块结构, 含虾蚓孔洞粪粒和钙质假菌丝体, 黑垆 土类型;

(4) $100-115 \mathrm{~cm}$, 古洪水滞流沉积层 (SWD3), 浊黄橙色, 沙质粉沙土, 均质块状, 疏松, 具有波状或者 水平层理;

(5) $115-135 \mathrm{~cm}$, 古土壤层 $\left(\mathrm{S}_{0 \text { 中上 }}\right)$, 浊棕色, 粉沙质地, 团块结构, 含蚯蚂孔洞粪粒和钙质假菌丝体, 黑 垆土类型;

(6) $135-180 \mathrm{~cm}$, 古洪水滞流沉积层 (SWD2), 浊黄橙色, 沙质粉沙土, 均质块状, 疏松, 具有波状或者 水平层理;

（7） $180-215 \mathrm{~cm}$, 古土壤层 $\left(\mathrm{S}_{0 \text { 中下 }}\right)$, 浊棕色, 粘土质粉沙, 团粒结构, 含蝤蚂孔洞粪粒和钙质假菌丝体, 黑垆土类型;

(8) $215-240 \mathrm{~cm}$, 古洪水滞流沉积层 (SWD1), 浊黄橙色, 沙质粉沙土, 均质块状, 疏松, 具有波状或者 水平层理;

(9) $240-270 \mathrm{~cm}$, 古土壤层 $\left(\mathrm{S}_{0 \text { 下 }}\right)$, 浊棕色, 粘土质粉沙, 团粒结构, 含蚯蚓孔洞粪粒和大量钙质假菌丝 体, 黑垆土类型;

（10） $270-295 \mathrm{~cm}$, 过渡黄土层 $\left(\mathrm{L}_{\mathrm{t}}\right)$, 浊橙色, 沙质粉沙土, 块状结构, 疏松, 含有钙质假菌丝体;

（11） $295-? \mathrm{~cm}$, 黄土层 $\left(\mathrm{L}_{1}\right)$, 浊黄橙色, 沙质粉沙土, 块状结构, 疏松, 典型的马兰黄土, 未见底.

在实验室内, 将全部样品置于室内自然风干, 然后对其进行磁化率、粒度成分的分析测试. 磁化率的测 定是取研磨后的风干样品 $10 \mathrm{~g}$, 用英国 Bartington 公司生产的 MS-2B 型磁化率仪分别对每个样品进行高频 和低频测量 3 次, 取平均值, 其测量精度为 $1 \%$. 粒度成分测量是取约 $1 \mathrm{~g}$ (精度为 $0.0001 \mathrm{~g}$ ) 的风干土样, 先后加人 $10 \%$ 的 $\mathrm{H}_{2} \mathrm{O}_{2}$ 和 $10 \%$ 的 $\mathrm{HCl}$ 除去有机质和钙质胶结物, 静置后加人适量 $\left(\mathrm{NaPO}_{3}\right)_{6}$ 使颗粒充分分 散, 用英国 Malvern 公司生产的 Mastersizer-S 型激光粒度仪测量, 测量精度为 $1 \%$. 关于 CHZ 剖面的年代, 首先是通过与黄土高原全新世风成黄土一土壤剖面进行土壤地层学和气候地层学对比分析, 建立基本的年 代框架; 其次是通过 OSL 测年, 获得一些关键性层位的年代数据, 进而确定出古洪水水文事件的发生 年代(1).

\section{3 实验结果分析与年代的确定}

磁化率在半干旱黄土地区对环境变化是非常敏感的, 因此常被用作环境变迁的代用指标, 反映气候随

(1) 王夏青, 黄春长等. 北洛河宜君段全新世古洪水滞流沉积层研究. 审稿中. 
时间变化的总体特征 ${ }^{[28-30]}$. 从图 2 可以看出, 磁化率的变化曲线很好地指示了 $\mathrm{CHZ}$ 剖面的地层划分特征. 磁 化率的变化范围为 $41.7 \times 10^{-8}-101 \times 10^{-8} \mathrm{~m}^{3} / \mathrm{kg}$, 最高值均出现在古土壤亚层, 这表明古土壤形成时期气 候温暖湿润, 降水量多, 淋溶和淀积作用活跃, 风化成壤作用强烈. 黄土层 $\left(\mathrm{L}_{0}\right.$ 和 $\left.\mathrm{L}_{\mathrm{t}}\right)$ 的磁化率偏低, 说明黄土 形成时期气候干早少雨, 成壤作用微弱. 滞留沉积层 SWD 的磁化率很低, 剖面最小值出现在 SWD1, 这是因 为古洪水 SWD 是河流悬移质长距离搬运混合和沉积的产物, 其颗粒较粗, 含沙量较大, 含次生铁磁性矿物 很少, 沉积之后受到风化成壤作用影响微弱. SWD2 表层 (约 $10 \mathrm{~cm}$ ) 的磁化率较高, 可能是由于沉积之后风 化成壤作用改造所致.

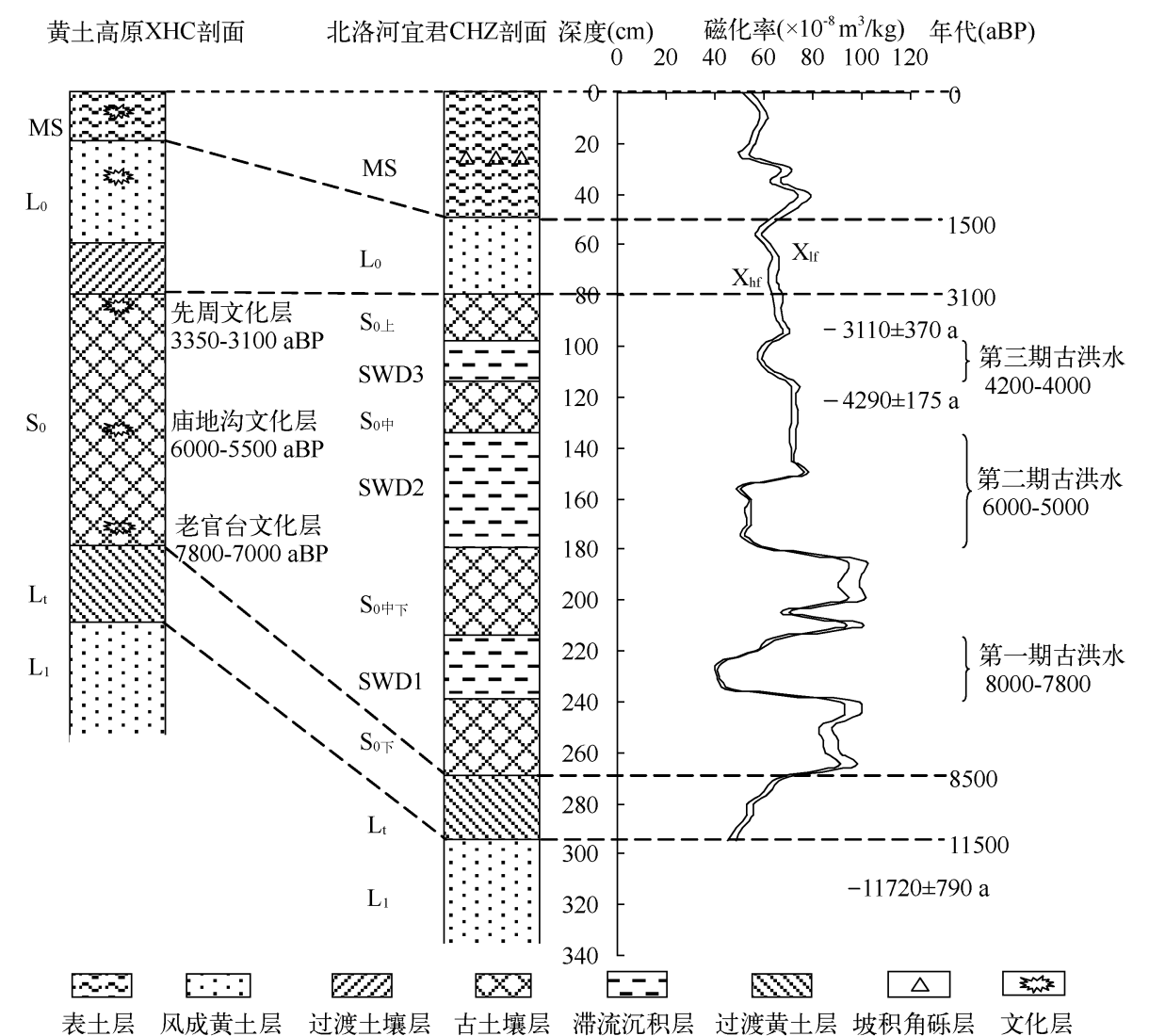

图 2 北洛河宜君 CHZ 剖面沉积地层划分、磁化率及其与黄土高原 XHC 全新世风成 黄土一土壤剖面地层年代对比

Fig. 2 Pedo-stratigraphic subdivision and magnetic susceptibility of the CHZ profile in the Beiluohe River valley and the correlation to Holocene loess-palaeosol profile in the Loess Plateau

粒度成分分析能够反映沉积物的来源、搬运营力以及所处的沉积环境, 是主要的气候变化代用指标. 粘 粒/粉沙比值的变化反映了当地受到生物气候环境制约的次生风化成壤改造强度. 北洛河 CHZ 剖面各层次 均以粉沙 $(0.002-0.063 \mathrm{~mm})$ 为主, 但每层的粘土、粉沙和细沙的含量均不相同 (图 3 ). 古土壤的粉沙含量 最多, 细沙含量较少, 中值粒径小, 粘粒/粉沙比值高, 这表明古土壤形成时经过了强烈的成壤改造作用. 黄 土层的粘土和粉沙含量比古土壤低, 而细沙含量和中值粒径比古土壤高, 粘粒/粉沙比值较低, 说明黄土形 成时期气候干旱, 沙尘暴强烈, 成壤改造作用微弱. 三期古洪水 SWD 均是以粉沙为主, 细沙次之, 粘土含量 最少, 且 SWD2 的细沙含量为剖面最高, 中值粒径大. 这些特征均是由河流的搬运分选沉积作用造成的. 粘 粒/粉沙比值很低, 说明其沉积之后受风化成壤作用影响很小.

黄土高原全新世风成黄土一土壤剖面地层年代框架已经相当成熟 ${ }^{[31-32]}$. 在半干旱季风区, 极端洪水的发 


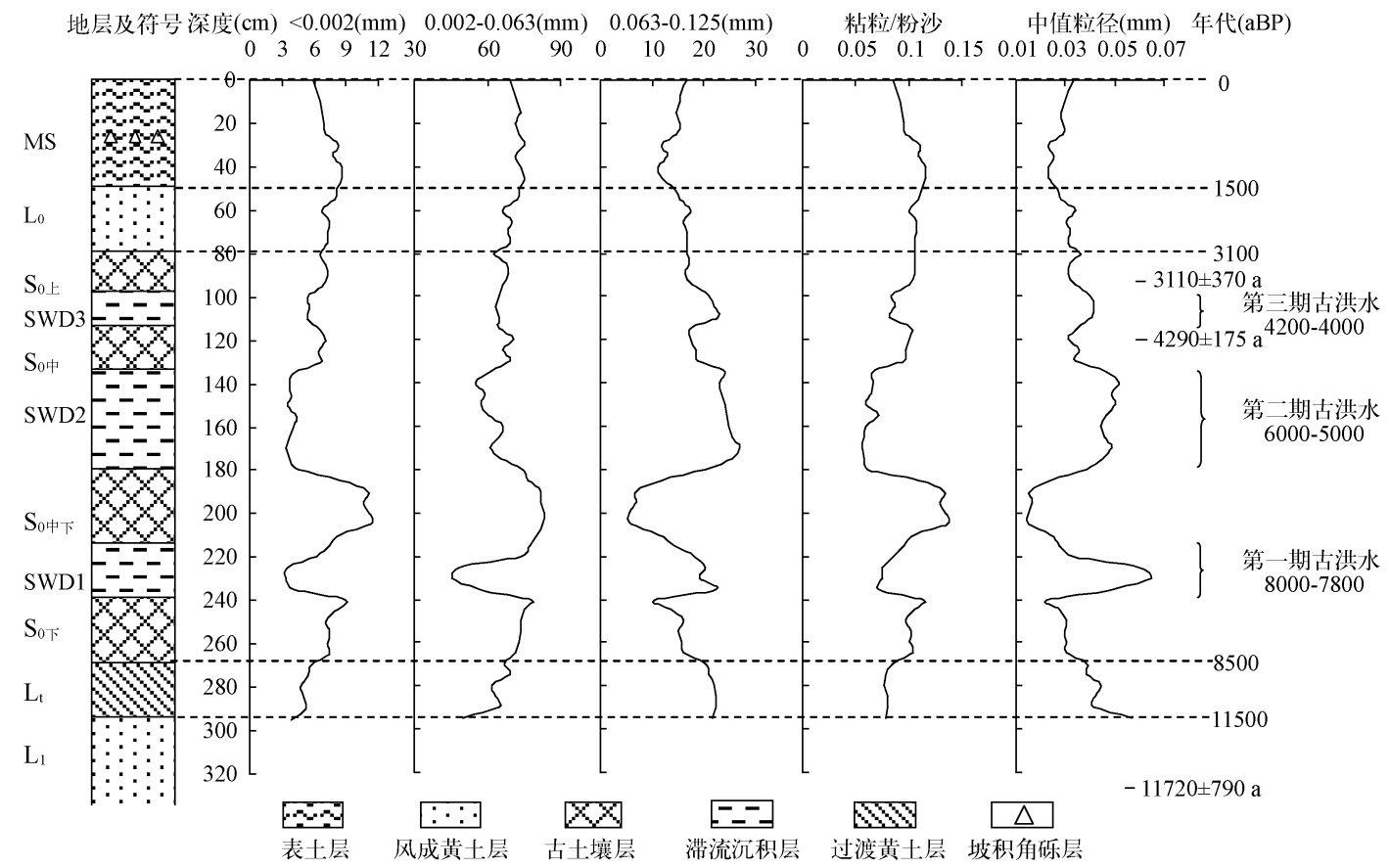

图 3 北洛河宜君 $\mathrm{CHZ}$ 剖面平均粒度成分和参数对比曲线

Fig. 3 Grain-size distribution in the CHZ profile in the Beiluohe River Valley

生往往是气候突变导致的. 根据风成黄土一土壤地层划分原则和同一气候系统下陕西长武县 XHC 剖面光释 光所测年代序列参照对比 ${ }^{[33]}$, 结合剖面实验分析结果和全新世大暖期气候突变事件研究结果 ${ }^{[34-36]}$, 基本确 定了 CHZ 剖面的年代框架 (图 2). 同时通过 OSL 测年, 在宜君 CHZ 剖面获得三个重要的年代数据, 即 $92.5 \mathrm{~cm}$ 为 $3110 \pm 370 \mathrm{a} ; 117.5 \mathrm{~cm}$ 为 $4290 \pm 175 \mathrm{a} ; 312.5 \mathrm{~cm}$ 为 $11720 \pm 790 \mathrm{a}$. 结合前人对于黄土高原全新世 黄土古土壤的断代及其与全球性气候变化和气候事件的对比, 确定 CHZ 剖面古土壤的年代范围为 $8500-$ $3100 \mathrm{aBP}$. 三层古洪水 SWD 均夹在古土壤间, 结合每个古土壤亚层的厚度, 根据年代内插法, 确定了这些古 洪水发生的年代为 $8000-7800 \mathrm{aBP}(\mathrm{SWD} 1), 6000-5000 \mathrm{aBP}(\mathrm{SWD} 2), 4200-4000 \mathrm{aBP}(\mathrm{SWD} 3)$. 这表明北 洛河古洪水事件的发生与全新世大暖期内的三次气候突变事件相对应.

\section{4 古洪水水文重建和验证}

\section{1 古洪水行洪断面的确定}

古洪水水文重建的最理想河段为河流基岩峡谷河段, 河槽抗蚀能力强, 断面变化小, 有利于计算行洪面 积. 而且, 基岩河段洪水涨落显著, 易于保存古洪水滞流沉积物 ${ }^{[1,7]}$. 北洛河宜君段地处黄土高原沟壑区, 河 槽地层为三叠系灰色砂页岩互层, 河流深切人基岩, 河槽狭窄. 该河段全新世以来地壳活动极其微弱, 河槽 形态特征稳定, 不冲不淤. 以 $\mathrm{CHZ}$ 剖面所在的河段断面作为河流行洪断面, 断面与河流洪水流向垂直. 断面 两岸较陡峭, 基岩裸露, 上部生长有灌木丛, 两岸均形成典型的一级阶地, 在右岸的阶地悬崖下存有完整的 全新世黄土-土壤沉积剖面, 阶地面开旺为耕地, 目前种植农作物. 我们对该断面河槽进行了精确测量, 通 过沉积学方法恢复了古洪水洪峰水位 (图 4), 并且计算了行洪时的断面面积.

\section{2 古洪水水位的恢复}

古洪水水文重建的首要工作就是根据古洪水滞流沉积层鉴别和恢复古洪水水位. 在全新世万年尺度, 河谷两侧能够保存下来的特大洪水沉积物, 往往处于河槽两侧相当高的位置. 国外的许多研究成果当中, 通 


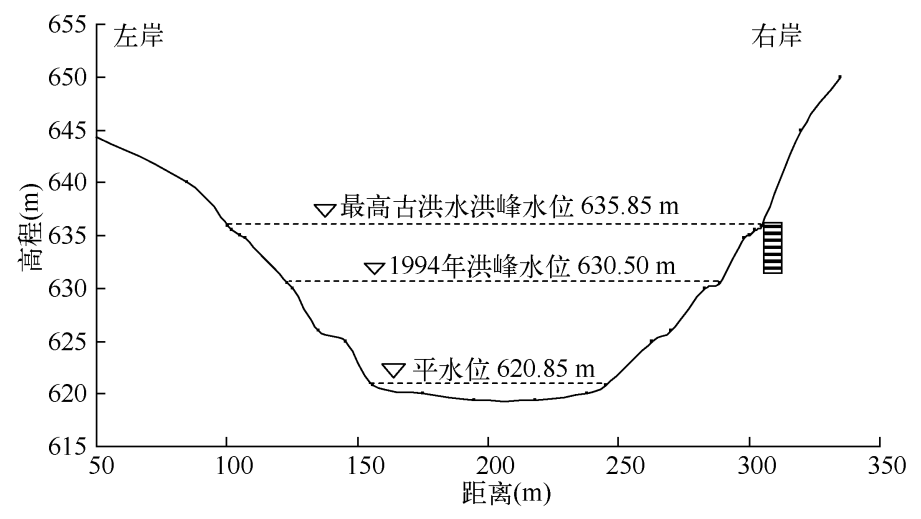

图 4 北洛河宜君 CHZ 地点河槽断面和古洪水最高洪峰水位

Fig. 4 Cross-section and the palaeoflood peak stage at the CHZ site of the Beiluohe River

常都是采用 SWD 顶面高程代替古洪水最低洪峰水位 ${ }^{[37-38]}$. 杨达源等通过研究提出古洪水滞流沉积物的侧 向尖灭点高程, 能够比较准确地指示古洪水的最高水位 ${ }^{[9,14]}$. CHZ 剖面位于右岸一级阶地的悬崖下, 因此, SWD 顶面为尖灭点高程, 按照杨达源等人的方法, 将 SWD 顶面高程作为古洪水的水位, 以此恢复古洪水的 行洪流量 (表 1). 根据野外用 GPS 对该河段河床高程测量, 并利用 1: 10000 地形图校正, 确定了河底高程为 $619.35 \mathrm{~m}$; 该河段为基岩型河床,因此在行洪断面中将河底看作是平直的. 由此确定了北洛河宜君 CHZ 全新 世三期古洪水的最高水位为 $635.85 \mathrm{~m}(\mathrm{SWD} 3)$, 最低水位为 $634.80 \mathrm{~m}(\mathrm{SWD} 1)$.

\section{3 古洪水洪峰流量计算}

全新世古洪水洪峰流量计算, 是在古洪水发生时间、洪峰水位推求及行洪断面考证的基础上进行的, 是 古洪水研究最重要的环节. 该阶段关系到计算模型的选择和各种水文参数的确定,是保证古洪水水文学成 果质量的关键. 目前, 根据水力学模型推求洪峰流量的方法比较多, 但各种方法均有其特定的使用条件 ${ }^{[39]}$. 北洛河宜君 CHZ 剖面古洪水 SWD 位于基岩峡谷河段,河槽稳定, 易于计算古洪水行洪断面面积. 根据河流 两岸的植被和冲刷状况, 也可以确定行洪时的樯率系数. 因此, 我们选择比降 - 面积法来恢复计算该剖面所 记录的古洪水的洪峰流量.

根据水力学模型确定的比降 - 面积法计算公式为:

$$
Q=\frac{1}{n} A R^{\frac{2}{3}} S^{\frac{1}{2}}
$$

式中, $Q$ 为洪峰流量 $\left(\mathrm{m}^{3} / \mathrm{s}\right) ; n$ 为河道鋉率系数; $A$ 为过流断面面积 $\left(\mathrm{m}^{2}\right) ; R$ 为水力半径 $(\mathrm{m}) ; S$ 为水面比降.

对于比降 $S$ 的确定, 由于北洛河该河段较顺直,河床为基岩, 全新世大暖期以来受冲刷和淤积影响小, 且河槽稳定, 因此以河床比降代替水面比降. 野外考察时用 GPS 和红外线测距仪精确测量高程和距离, 从而 得出 CHZ 古洪水 SWD 所处河段的比降为 $2.5 \%$.

对于河道鋉率系数 $n$, 北洛河宜君 CHZ 剖面所处河段较顺直, 夹于两弯道之间, 距离不远, 无宽广河漫 滩, 断面规整, 水流湍急, 水声较大. 左岸为基岩峭壁, 右岸黄土覆盖基岩, 有灌木丛生长. 河底比较均匀, 床 面比较平整. 特大洪水发生时, 洪水可将全部河槽及两岸的一级阶地淹没. 根据该河段河槽特征, 结合《水力 学》中糙率学所描述的天然河道的特征 ${ }^{[40]}$, 确定粘率值为 0.04 .

过水断面面积 $(A)$ 和湿周 $(L)$ 的计算采用微分法, 在 EXCEL 中利用行洪断面分别计算 $A$ 和 $L$. 根据水力 半径的计算公式: $R=A / L$,计算各期古洪水行洪时的水力半径 (表 1$)$.

将上述各参数值, 代人比降 - 面积法公式中, 计算出北洛河宜君 $\mathrm{CHZ}$ 剖面中各期古洪水的最大洪峰流 量 (表 1). 由此可知, 北洛河该河段全新世古洪水最大洪峰流量介于 $13600-14100 \mathrm{~m}^{3} / \mathrm{s}$ 之间. 
表 1 北洛河宜君 CHZ 断面全新世古洪水水文计算成果

Tab. 1 Reconstructed peak discharges of the Holocene palaeofloods at the CHZ section of the Beiluohe River

\begin{tabular}{ccccccccc}
\hline 古洪水期次 & $H(\mathrm{~m})$ & $h(\mathrm{~m})$ & $S$ & $n$ & $A\left(\mathrm{~m}^{2}\right)$ & $L(\mathrm{~m})$ & $R(\mathrm{~m})$ & $Q\left(\mathrm{~m}^{3} / \mathrm{s}\right)$ \\
\hline SWD3 & 635.85 & 16.5 & 0.0025 & 0.04 & 2289.27 & 209.01 & 10.95 & 14100 \\
SWD2 & 635.50 & 16.15 & 0.0025 & 0.04 & 2218.50 & 204.54 & 10.85 & 13600 \\
SWD1 & 634.80 & 15.45 & 0.0025 & 0.04 & 2208.15 & 195.41 & 11.30 & 13900 \\
\hline
\end{tabular}

\section{4 古洪水流量的水文验证}

通过对洪痕所指示的洪水洪峰流量进行恢复, 并结合水文站实测洪水的洪峰流量数据, 计算其误差, 可 验证古洪水洪峰流量恢复的正确性. CHZ 剖面旁发现的 1994 年洪痕低于 SWD3 顶面 $5.35 \mathrm{~m}$, 按照古洪水洪 峰流量的计算方法, 可知洪痕的洪水水位为 $630.50 \mathrm{~m}$. 因与 $\mathrm{CHZ}$ 剖面位于同一河段, 取水面比降 $S$ 为 0.0025 , 䊁率系数 $n$ 为 0.04 , 运用比降法可得洪痕所代表的洪水洪峰流量为 $6470 \mathrm{~m}^{3} / \mathrm{s}($ 表 2$)$. 北洛河洑头水 文站实测的最大洪峰流量为 $6280 \mathrm{~m}^{3} / \mathrm{s}\left(1994\right.$ 年 9 月 1 日 8 时), 水位涨幅 $12.29 \mathrm{~m}$, 流量涨率为 $1790 \mathrm{~m}^{3} / \mathrm{s}$, 洪水过程径流总量为 $1.9381 \times 10^{8} \mathrm{~m}^{3}[23]$. 根据实测的最大洪峰流量可知, 利用比降法恢复的洪峰流量误差 为 $2.96 \%$, 由此可见,我们采用比降法对北洛河全新世古洪水洪峰流量恢复的计算结果是合理的、可信的.

表 2 北洛河宜君 CHZ 断面 1994 年洪水洪痕洪峰流量计算成果

Tab. 2 Reconstructed flood peak discharges at the CHZ section of the Beiluohe River in 1994

\begin{tabular}{ccccccccc}
\hline 洪水发生时(月一日) & $H(\mathrm{~m})$ & $h(\mathrm{~m})$ & $S$ & $n$ & $A\left(\mathrm{~m}^{2}\right)$ & $L(\mathrm{~m})$ & $R(\mathrm{~m})$ & $Q\left(\mathrm{~m}^{3} / \mathrm{s}\right)$ \\
\hline $09-01$ & 630.50 & 10.63 & 0.0025 & 0.04 & 1314.65 & 168.43 & 7.81 & 6470 \\
\hline
\end{tabular}

4.5 北洛河中游万年尺度洪水流量 - 频率关系分析

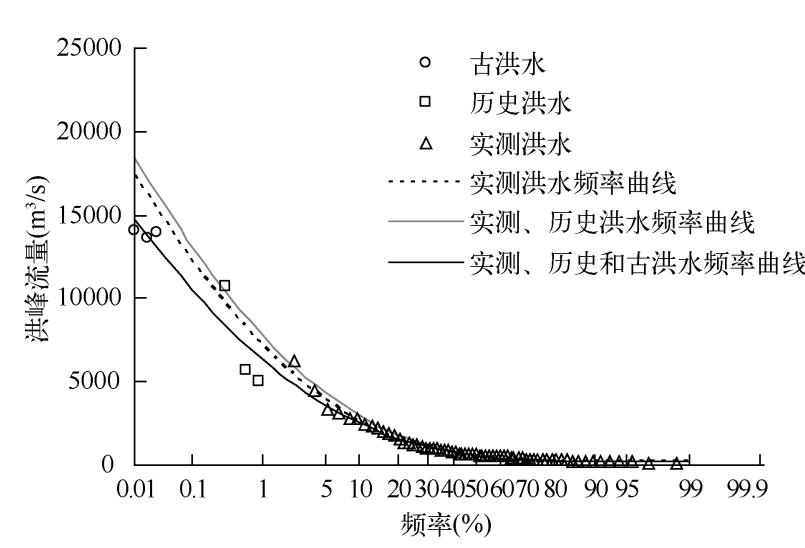

图 5 北洛河洑头水文站实测洪水、历史洪水与 古洪水洪峰流量-频率关系曲线

Fig. 5 Flood peak discharge-frequency curves established by gauged flood, historical flood and palaeo-flood data at the Zhuangtou station on the Beiluohe River
选取北洛河洑头水文站 $1933-2000$ 年 历年最大洪水洪峰流量资料作为实测洪水 系列, 结合调查得到的 1662 年、1855 年和 1932 年的历史洪水洪峰流量, 以及我们根 据宜君 CHZ 剖面古洪水沉积层恢复的最大 洪峰流量, 将该水文站的洪水洪峰流量数 据扩展到万年尺度, 通过频率分析计算, 做 出该水文站万年尺度洪峰流量一频率和洪 峰流量-重现期关系曲线 (图 5).

使用实测洪峰流量和历史洪水洪峰流 量计算频率, 得出万年一遇的洪水洪峰流 量为 $18443 \mathrm{~m}^{3} / \mathrm{s}$, 千年一遇的洪水洪峰流量 为 $13006 \mathrm{~m}^{3} / \mathrm{s}$. 古洪水水文计算成果得出万 年一遇洪水的洪峰流量为 $14740 \mathrm{~m}^{3} / \mathrm{s}$, 千年 一遇洪水的洪峰流量为 $10454 \mathrm{~m}^{3} / \mathrm{s}$ ( 图 5). 这说明加人古洪水水文分析成果后, 北洛 河万年尺度洪水洪峰流量 - 频率关系更加

可靠. 这对于北洛河流域水利工程、防洪工程和城镇建设的洪水设计是十分重要的.

\section{5 讨论与结论}

北洛河是黄河中游的一条主要多泥沙河流. 野外考察在北洛河中游宜君段基岩峡谷蔡河站附近, 发现 了完整的全新世风成黄土一土壤剖面. 其中夹着记录了特大洪水的全新世古洪水滞流沉积物. 这些古洪水滞 
流沉积层夹在全新世中期古土壤 $\mathrm{S}_{0}$ 中,层次清晰, 呈波状、水平状层理,其颜色、粒度成分和结构等方面,与 古土壤层有着非常明显的区别. 经过仔细的观察研究, 系统采样和室内实验分析, 确定了这些 SWD 沉积物 为北洛河特大古洪水的悬移质泥沙在高水位滞流环境下的沉积物. 这些古洪水 SWD 的磁化率低于黄土和 古土壤, 且分层界限明显. 其粒度成分是以粉沙为主, 细沙次之, 粘土含量最少; 各成分含量与黄土和古土壤 均不同; 中值粒径较大, 分选性好, 粘土/粉沙比值小, 这些特征均是由河流洪水的长距离搬运分选沉积作用 造成的. 进一步的古洪水水文学研究,恢复了这些古洪水的洪峰水位. 在详细勘测的基础上, 选择合理的参 数,采用比降 - 面积法水文模型, 恢复了该河段的古洪水洪峰流量. 结果表明全新世时期北洛河万年尺度的 特大洪水洪峰流量介于 $13600-14100 \mathrm{~m}^{3} / \mathrm{s}$ 之间. 这是北洛河洑头水文站实测最大洪峰流量的 $2.0-2.5$ 倍. 利用该方法计算 1994 年洪水洪痕所代表的最大洪峰流量, 与洑头水文站实测最大洪峰流量的误差为 $2.96 \%$, 这说明了我们利用古洪水水文学方法恢复得到的古洪水洪峰流量是合理的. 这就使得北洛河流域 的洪水数据序列延长到万年尺度, 从而能够建立起更加精确地洪峰流量 - 频率关系曲线. 由此得到北洛河 中游万年一遇洪水的洪峰流量为 $14740 \mathrm{~m}^{3} / \mathrm{s}$, 千年一遇洪水的洪峰流量为 $10454 \mathrm{~m}^{3} / \mathrm{s}$. 这些数据则更加确切 地反映出万年尺度内特大洪水的规模, 对北洛河该流域的水利、交通和城乡建设提供了可靠的依据.

黄土高原地区全新世气候变化研究已经相当成熟. 在全新世早期 (11500-8500 aBP) ,气候由干冷逐渐 转向暖湿,堆积了过渡性黄土层; 全新世中期 ( $8500-3100 \mathrm{aBP})$, 气候温暖湿润,生物成壤作用强烈, 高原面 形成肥沃的黑垆土土壤, 河谷盆地形成了淋溶性的褐色土土壤, 因此将这个时期称为大暖期; 全新世晚期 $(3100-0 \mathrm{aBP})$ 气候逐渐趋向于干冷, 沙尘暴活动堆积了近现代黄土层 ${ }^{[32-33]}$. 国内外有大量高分辨率研究成 果表明,全新世大暖期里曾经发生了三次气候突变事件, 分别为 8200-7800 aBP、6000-5000 aBP 和 4200$4000 \mathrm{aBP}^{[5-6,34-36,41-43]}$. 这些气候事件导致区域气候很不稳定, 时而暴雨频发, 时而雨水缺乏, 从而导致特大洪 水或严重的干旱发生. 研究现代季风气候和洪水的关系发现, 异常的大气循环模式产生的暴雨, 常常导致特 大洪水事件的发生 ${ }^{[44]}$. 根据北洛河 CHZ 地点全新世地层剖面古洪水 SWD 在古土壤中的相对位置, 结合气 候地层学对比和 OSL 测年数据,并且使用年代内插法,可以确定北洛河三期古洪水事件的发生年代,与三个 全球性气候突变事件一致. 这些洪水事件发生在 8000-7800 aBP( SWD1)、6000-5000 aBP( SWD2) 和 4200 $4000 \mathrm{aBP}(\mathrm{SWD} 3)$. 这也表明全新世大暖期三个气候突变事件, 影响了黄土高原的气候, 由于气候不稳定而 形成的特大暴雨,在北洛河流域形成了三期特大洪水事件. 因而这些古洪水事件是全新世气候突变的结果. 所以本文的研究结果对于全面地理解全球变化及其区域性影响规律是十分重要的.

北洛河 CHZ 剖面中记录的特大洪水事件,不仅完善了该流域全新世特大洪水序列, 为水利工程建设提 供了基础性数据,也为我们深人地理解黄土高原全新世大暖期内的季风气候突变的内涵和外在表现提供了 新的证据.

\section{6 参考文献}

[ 1 ] Benito G, Sopea A, SnchezMoya Y et al. Palaeoflood record of the Tagus River (Central Spain) during the Late Pleistocene and Holocene. Quaternary Science Reviews, 2003, 22 (15-17) : 1737-1756.

[ 2 ] Benito G, Baker VR, Gregory KJ. Palaeohydrology and environmental change. Wiley: Chichester, 1998: 1-10.

[ 3 ] 李长安, 黄俊华, 张玉芬等. 黄河上游末次冰盛期古洪水事件的初步研究. 地球科学: 中国地质大学学报, 2002, $27(4): 456-458$.

[4] 朱 诚, 于世永, 卢春成. 长江三峡及江汉平原地区全新世环境考古与异常洪涝灾害研究. 地理学报, 1997, $52(3): 268-278$.

[ 5 ] 吴文祥, 葛全胜. 全新世气候事件及其对古文化发展的影响. 华夏考古, 2005, (3) : 60-67.

[ 6 ] 吴文祥, 刘东生. $4000 \mathrm{aBP}$ 前后降温事件与中华文明的诞生. 第四纪研究, 2001, 21(5): 443-451.

[ 7 ] 詹道江, 谢悦波. 洪水计算的新进展: 古洪水研究. 水文, 1997, (1) : 1-6.

[ 8 ] Baker VR. Paleoflood hydrology and extreme flood events. Journal of Hydrology, 1987, 96 : 79-99.

[ 9 ] Yang DY, Yu B, Xie YB et al. Sedimentary records of large Holocene floods from the middle reaches of the Yellow River, China. Geomorphology, 2000, 33(1-2) : 73-88.

[10 ] Huang CC, Pang JL, Zha XC et al. Extraodinary floods of $4100-4000$ aBP recorded at the late Neolithic Ruins in the Jing- 
he river gorges, middle reach of the Yellow river, China. Palaeogeography Palaeoclimatology Palaeoecology, 2010,289 $(1-4): 1-9$.

[11] Zha XC, Huang CC, Pang JL. Palaeofloods recorded by slackwater deposits on the Qishuihe River in the Middle Yellow River. Journal of Geographical Sciences, 2009, 19: 681-690.

[12] 谢悦波，杨达源. 古洪水平流沉积基本特征. 河南大学学报, 1998, 26(6) : 5-10.

[13] 谢悦波, 王文辉, 王 平. 古洪水平流沉积粒度特征. 水文, 2000, 20(4): 18-20.

[14] 谢悦波, 费宇红, 沈起鹏. 古洪水平流沉积与水位. 地球学报, 2001, 22(4) : 320-323.

[15] 詹道江, 谢悦波. 古洪水研究. 北京: 中国水利水电出版社, 2001: 49-90.

[16] 查小春, 黄春长, 庞奖励. 关中西部漆水河全新世特大洪水与环境演变. 地理学报, 2007, 62 (3): 291-300.

[17] 姚 平, 黄春长, 庞奖励等. 北洛河中游黄陵洛川段全新世古洪水研究. 地理学报, 2008, 63(11): 1198-1206.

[18］李瑜琴, 黄春长, 查小春等. 泾河中游龙山文化晚期特大洪水水文学研究. 地理学报, 2009, 64(5): 541-552.

[19］崔文艺，王武成. 北洛河流域中上游水文特性分析及防洪减灾对策. 陕西水利, 2009，(3)：42-44.

[20］师 奎. 北洛河中游洪水频率分析. 新西部(下半月), 2009, 10: 76-77.

[21] 景 可. 泾河、北洛河泥沙输移规律. 人民黄河, 1999, 21(12): 18-19.

[22] 莫 莉, 穆兴民, 王 勇等. 近 50 多年来北洛河水沙变化特征及原因分析. 泥沙研究, 2009, (6) : 30-36.

[23］景效礼，宋志林. 陕西省北洛河“94.8”暴雨洪水分析. 水文, 2000, 20(1) : 56-59.

[24] 陕西师范大学地理系编写组. 延安地区地理志. 西安: 陕西人民出版社, 1983: 78-82.

[25] 陕西黄河小北干流志编纂委员会. 陕西黄河小北干流志. 郑州: 黄河水利出版社, 1999: 1-50.

[26] 余汉章. 陕西水文. 西安: 陕西科学技术出版社, 1987: 276-282.

[27] 再大川, 刘 斌, 王 宏等. 黄河中游典型支流水土保持措施减洪减沙作用研究. 郑州: 黄河水利出版社, 2006: 275-290.

[28] 黄春长. 环境变迁. 北京: 科学出版社, 1997: 122-124.

[29］刘秀铭, 刘东生, Show J. 中国黄土磁性矿物特征及其古气候意义. 第四纪研究, 1993, (3) : 281-287.

[30］刘秀铭, 刘东生, Heller F 等. 黄土频率磁化率与古气候冷暖变换. 第四纪研究, 1990, (1) : 42-50.

[31] 刘东生. 黄土与环境. 北京: 科学出版社, 1985: 62-81.

[32] 黄春长, 庞奖励, 黄 萍等. 关中盆地西部黄土台塬全新世气候事件研究. 干旱区地理, 2002, 25(1): 10-15.

[33] Huang CC, Pang JL, Su HX et al. The Ustic Isohumisol (Chernozem) distributed over the Chinese Loess Plateau: modern soil or palaeosol? Geoderma, 2009, 150(3-4) : 344-358.

[34] 施雅风, 孔昭宸, 王苏民等. 中国全新世大暖期的气候波动与重要事件. 中国科学 ( B 辑: 化学), 1992, (12): 1300-1308.

[35］施少华. 中国全新世高温期中的气候突变事件及其对人类的影响. 海洋地质与第四纪地质, 1993, 13(4) : 65-73.

[36] 覃嘉铭, 袁道先, 程 海等. 新仙女木及全新世早中期气候突变事件: 贵州茂兰石笋氧同位素记录. 中国科学 ( D 辑:地球科学), 2004, 34(1): 69-74.

[37] Klaus H, Jan TH. Apaleohydrologic reinterpretation of the Homeb Silts, Kuiseb River, central Namib Desert (Namibia) and paleoclimatic implications. Catena, 2002, 48: 107-130.

[38 ] Jones AP, Shimazu H, Oguchi T et al. Late Holocene slackwater deposits on the Nakagawa River, tochigi prefecture, Japan. Geomorphology, 2001, 39: 39-51.

[39] 詹道江, 叶守泽. 工程水文学. 北京: 中国水利水电出版社, 2000: 276-277.

[40] 武汉水利电力学院水力学教研室编. 水力学. 北京: 高等教育出版社, 1986: 335-336.

[41] Liu CL, Wang ML, Jiao PC et al. Holocene Yellow Silt Layers and the Paleoclimate Event of 8200 aB. P. in Lop Nur, Xinjing, NW China. Acta Geographica Sinica, 2003, 77(4) : 514-518.

[42] 邵晓华, 汪永进, 程 海等. 全新世季风气候演化与干旱事件的湖北神农架石笋记录. 科学通报, 2006, 51(1): $80-86$.

[43] 史 威, 朱 诚, 王富葆等. 宁镇及宜溧地区全新世中晚期典型沉积相与 $5700 \mathrm{aBP}$ 前后的气候突变事件. 地理 科学, 2007, 27(4) : 512-518.

[44] Huang CC, Pang JL, Zha XC et al. Impact of monsoonal climatic change on Holocene overbank flooding along Sushui River, middle reach of the Yellow River, China. Quaternary Science Reviews, 2007, 26: 2247-2264. 